\title{
TYROSINASE INHIBITORY ACTIVITIES AND QSAR MODELS OF KOJYL THIOETHER DERIVATIVES
}

\author{
Yusnita Rifai ${ }^{1,}$, Fazrul Permadi ${ }^{1}$, Muhammad Nur Amir ${ }^{2}$ \\ and Muhammad Aswad ${ }^{1}$ \\ ${ }^{1}$ Pharmaceutical Chemistry Laboratory, Faculty of Pharmacy, Hasanuddin University, \\ Makassar 90245, Indonesia \\ ${ }^{2}$ Pharmacology and Toxicology Laboratory, Faculty of Pharmacy, Hasanuddin University, \\ Makassar 90245, Indonesia \\ ${ }^{\square}$ Corresponding Author: yusnita@fmipa.unhas.ac.id
}

\begin{abstract}
Quantitative Relationship of Structures and Activities (QSAR) models on the kojyl thioether derivative compounds are performed to determine the relationship between the properties of the compound molecules (descriptors) and their biological activity as tyrosinase inhibitors. In this research, we obtain a valid QSAR equation which is then used to design new compounds based on kojyl thioether properties. Descriptor calculations are performed using a hyperchem 8.0 application with a PM3 semi-empirical geometry optimization method. Based on the QSAR equation, 15 out of 19 compounds derived from kojic acid containing thioether can be proposed to be analogs of new tyrosinase inhibitors. All compounds were not hepatotoxic and have better predicted inhibitory activity values $\left(\mathrm{pIC}_{50}\right)$ as tyrosinase inhibitors than the leading compound. They did not cause AMES toxicity either cause skin sensitivity. The interaction between compounds and tyrosinase enzymes shows that all compounds have hydrogen bonds and steric interactions in the amino acid residue His263.
\end{abstract}

Keywords: Tyrosinase, QSAR, Docking, Kojyc Acid, Kojyl Thioether

RASĀYAN J. Chem., Vol. 14, No.3, 2021

\section{INTRODUCTION}

Skin hyperpigmentation is a disorder of skin color caused by excessive melanin production due to increased melanocytes and tyrosinase activity. ${ }^{1}$ To overcome this problem, usually, people will use skin lightening products. There are already plenty of whale-whitening ingredients in which the main mechanism of action of the active substance is to reduce the amount of melanin. The amount of melanin affects the darkness of a person's skin color.

One way to reduce the amount of melanin is by inhibiting the action of the enzyme tyrosinase. Examples of active substances with tyrosinase inhibitor mechanism in skin whitening ingredients such as hydroquinone, kojic acid, arbutin, azelaic acid, and vitamin $\mathrm{C}^{2}$ But hydroquinone, retinoic acid, azelaic acid, and vitamin $\mathrm{C}$ can cause irritation, cytotoxics, contact dermatitis, redness with a rather slow therapeutic response and low activity. ${ }^{3}$

The discovery of quantum mechanics which has emerged in the field of computational chemistry minimizes trial and error processes in drug discovery. Research costs thus can be reduced and research time can be shortened. Computational chemistry uses the results of theoretical chemistry that are put into a computer program so that it can calculate the properties of molecules and their changes. The properties of drugmolecules are closely related to drug activity. Computational chemistry can also simulate large systems in the form of gases, liquids, solids, or liquid crystals. ${ }^{4}$

In this research, we perform QSAR models on kojyl thioether derivative compounds to determine the relationship between the properties of the compound molecules (descriptors) and their biological activity as tyrosinase inhibitors. The equation of QSAR is then used to design new compounds based on the properties of kojyl thioether. The design of compounds is then essential to further study the interaction of derivatives with the target protein (tyrosinase enzyme) through molecular docking analysis. 


\section{Compound Optimization and Descriptor Calculations \\ EXPERIMENTAL}

All 14 compounds were geometry optimized using hyperchem 8.0 software with the parameterized Semiempirical Model 3 (PM3) method using the polak-ribiere algorithm, rms gradient $0.01 \mathrm{kcal} / \mathrm{mol}$. The results of the descriptor calculations are total energy (PM3_E), dipole moment (PM3_Dipol), atomic net charge energy (PM3_q), formation heat (PM3_HF), bond energy (PM3_Eik), atomic isolation energy (PM3_Eis), electronic energy (PM3_Eele), and formation heat (PM3_HF), bond energy (PM3_Eik), atomic isolation energy (PM3_Eis), electronic energy (PM3_Eele), and heat formation (PM3 3 HF). Core interactions (PM3_Eint) are obtained from the .log file when geometry optimization, HOMO energy (PM3_HOMO) and LUMO energy (PM3_LUMO) are obtained in the orbitals menu while mass (BM), partition coefficient $(\log \mathrm{P})$ and Vander Waals volume (Vol) are obtained through QSAR property menu. The selection of descriptors already represents electronic, steric and hydrophobic parameters.

\section{Build the QSAR Model}

Multilinear regression analysis was performed to obtain the QSAR equation with the help of SPSS 25 software using the stepwise, backward and enter methods. The independent variable used was the compound descriptor while the dependent variable was the tyrosinase inhibitor activity of the kojic thioether derivative expressed in $\mathrm{pIC}_{50}$. The HKSA equation was chosen based on statistical criteria such as correlation coefficient (r), coefficient of determination (R2), F value and standard error (SE). In addition, the leave one out (LOO) cross-validation test is also carried out to ensure the validity of the selected equation by looking at the largest value of the cross-validation coefficient (q2) ( $\geq 0.5)$. LOO is done using each compound in the fitting data being eliminated then a new HKSA equation is built and the activity of the compound is predicted using a new equation without the compound. This was repeated for 14 compounds..$^{5-8}$

\section{New Compound Design and Molecular Tethering}

Based on the QSAR equation, the structure modification is done to obtain new thioether kojic derivatives which have better activity. Modification is done by adding benzene groups to be modified again by adding hydroxy, methoxy, and halogens. Molecular tethering is performed using Molegro Virtual Docker (MVD) software with an enzyme of a $2 \mathrm{y} 9 \mathrm{x}$ pdb code. The molecular tethering process is carried out on the active side with native ligands, namely position $\mathrm{X}=-0.45, \mathrm{Y}=26.5$ and $\mathrm{Z}=-44.78$ with a gird radius of 15 and a resolution of $0.3 \AA$.

\section{Inhibitory Activity Assay}

A $80 \mu \mathrm{L}$ phosphate buffer is placed on the micro plate. The sample solution is put into each well until a concentration of 0.1 is obtained; $1 ; 10 ; 100$; and $1000 \mu \mathrm{M}$ for all 14 compounds. L-Tyrosine substrate solution was added to the micro plate by $5 \mu \mathrm{M}$. The mixture was then incubated for 10 minutes at room temperature $\left( \pm 27^{\circ} \mathrm{C}\right) .{ }^{9}$ MTE was put into each of the 80 micro plate wells. The mixture is then homogenized and re-incubated at the same temperature for 30 minutes. Each test concentration was repeated three times and made control (containing phosphate buffer, $5 \mu \mathrm{M}$ L-Tyrosine, and $20 \mathrm{U}$ MTE). The test compound was then measured for absorbance at a wavelength of $490 \mathrm{~nm}$ using a microplate reader. $\frac{\mathrm{u}}{\mathrm{mL}}$

\section{RESULTS AND DISCUSSION}

\section{In vitro inhibitory Activities ( IC $\left._{50}\right)$ and In silico inhibitory Activities (pIC (10) $_{\text {of }}$ Compounds}

Data on the structure and activity of 14 kojyl thioeter derivatives as tyrosinase inhibitors obtained can be seen in Figure 1 and Table 1. Inhibitory activities in the form of $\mathrm{IC}_{50}$ all compounds were converted to $\mathrm{pIC}_{50}$ $\left(-\log \mathrm{IC}_{50}\right)$. Compound $\mathrm{A} 5$ has the best $\mathrm{IC}_{50}$ and $\mathrm{pIC}_{50}$ values thus are considered to be the leading compound (Table-1).

Table-1: Derivatives of Kojyl Thioeter Compounds and Their Activities

\begin{tabular}{c|c|c|c|c}
\hline No & Compound & Side chain & $\mathrm{IC}_{50}(\mu \mathrm{M})$ & $\mathrm{pIC}_{50}$ \\
\hline 1 & $\mathrm{~A} 1$ & $\mathrm{R}=-\mathrm{CH}_{5}$ & 11.05 & -1.0433 \\
\hline 2 & $\mathrm{~A} 2$ & $\mathrm{R}=-\mathrm{C}_{3} \mathrm{H}_{7}$ & 8.93 & -0.9509 \\
\hline
\end{tabular}

2063 
RASĀYAN J. Chem.

Vol. 14 | No. 3 |2062-2067| July - September | 2021

\begin{tabular}{|c|c|c|c|c|}
\hline 3 & A3 & $\mathrm{R}=-\mathrm{C}_{4} \mathrm{H}_{9}$ & 12.68 & -1.1031 \\
\hline 4 & A4 & $\mathrm{R}=-\mathrm{C}_{5} \mathrm{H}_{11}$ & 15.16 & -1.1806 \\
\hline 5 & A5 & $\mathrm{R}=-\mathrm{C}_{6} \mathrm{H}_{15}$ & 0.087 & 1.0604 \\
\hline 6 & A6 & $\mathrm{R}=-\mathrm{C}_{7} \mathrm{H}_{15}$ & 12.33 & -1.0909 \\
\hline 7 & A7 & $\mathrm{R}=-\mathrm{C}_{8} \mathrm{H}_{17}$ & 40.18 & -1.6040 \\
\hline 8 & A8 & $\mathrm{R}=-\mathrm{C}_{6} \mathrm{H}_{11}$ & 59.41 & -1.7738 \\
\hline 9 & B1 & $\mathrm{R}=-\mathrm{C}_{5} \mathrm{H}_{11}$ & 2.24 & -0.3502 \\
\hline 10 & $\mathrm{~B} 2$ & $\mathrm{R}=-\mathrm{C}_{6} \mathrm{H}_{13}$ & 18.09 & -1.2574 \\
\hline 11 & B3 & $\mathrm{R}=-\mathrm{C}_{6} \mathrm{H}_{11}$ & 1.68 & -0.2253 \\
\hline 12 & $\mathrm{C} 1$ & $\mathrm{R}=-\mathrm{C}_{5} \mathrm{H}_{11}$ & 70.11 & -1.8457 \\
\hline 13 & $\mathrm{C} 2$ & $\mathrm{R}=-\mathrm{C}_{6} \mathrm{H}_{13}$ & 72.63 & -1.8611 \\
\hline 14 & $\mathrm{C} 3$ & $\mathrm{R}=-\mathrm{C}_{6} \mathrm{H}_{11}$ & 77.19 & -1.8875 \\
\hline
\end{tabular}

\section{QSAR Models}

Fig.-1: The Basic Structure of Kojyl Thioeter

QSAR begins with the geometry optimization of all compound fittings using Hyperchem 8.0 software to get the descriptor values of these compounds. The purpose of geometry optimization is to make the surface potential energy of the compound close to 0 . Multilinear regression analysis is performed to obtain the QSAR equation. QSAR equations obtained are then ranked based on statistical parameters such as r, R2, F and SE values. The 5 best equations were selected which were then tested for validation using LOO crossvalidation to see the value of q2. Obtained the best QSAR equation with parameters $r=0.946, \mathrm{R} 2=0.901$, Fhit $/ \mathrm{Ftab}=5.6, \mathrm{SE}=0.436$ and $\mathrm{q} 2=0.8246$ which means valid. $\mathrm{pIC}_{50}=-922,517+15,872 *$ ELUMO $436,654 * \mathrm{qC} 4-209,509 * \mathrm{qC} 5+1,0008 \mathrm{e}^{-5 *}$ Eint [1].

Table-2: Predictors used and the Best QSAR Equation Statistical Data

\begin{tabular}{c|c|c|c|c|c}
\hline Descriptor & $\mathrm{r}$ & $\mathrm{R} 2$ & Fhit / Ftab & SE & q2 \\
\hline $\begin{array}{c}\text { PM3_ELUMO, PM3_qC4, PM3_qC5, } \\
\text { PM3_Eint }\end{array}$ & 0.949 & 0901 & 5.6 & 0.436 & 0.8246 \\
\hline
\end{tabular}

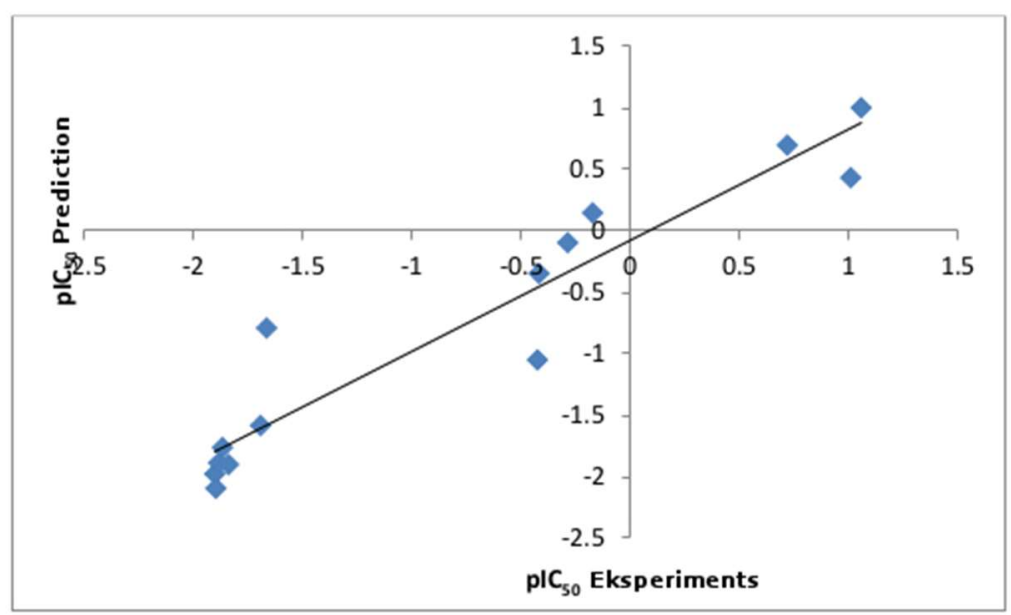

Fig.-2: Relationship between $\mathrm{pIC}_{50}$ Experiments $\mathrm{Vs}_{\mathrm{s}} \mathrm{pI}_{50}$ Predictions of Thioether Kojyl Derivatives 
RASĀYAN J. Chem.

Vol. 14 | No. 3 |2062-2067| July - September | 2021

Based on the QSAR model, electronic parameters are the only parameters that affect the activity of tyrosinase inhibitors of kojyl thioether derivatives. The bond between receptor compounds is usually influenced by steric and electronic parameters but electronic parameters have a greater role. Hydrophobic parameters only affect the distribution of compounds and the biological membrane penetration process while the activity data obtained are only in vitro tests that do not require the biological membrane penetration process but rather the binding of the compound-receptors. The greater ELUMO and Eint will increase tyrosinase inhibitor activity. Conversely, even a small amount of qC4 and qC5 will increase its activity.

\section{Molecular Tethering}

Modification of the kojyl thioether compound was not carried out on the structure of pyranone or its enol because modifying the part would eliminate tyrosinase activity. From the fitting data, the best compound is A5 which has a side chain in the form of cyclohexil. This compound should be used as a guiding compound in structural modification. Chemically, a new compound can be proposed as a tyrosinase inhibitor if possible, to be synthesized. So that the structure of cyclohexil is replaced with the structure of benzene which is then modified by the addition of $\mathrm{OH}, \mathrm{OCH}_{3}, \mathrm{Cl}, \mathrm{Br}$ and $\mathrm{I}$.

Fifteen out of nineteen compounds (compounds 4 to 18) have better activities than the guiding compound B2. They are also less toxic(http://biosig.unimelb.edu.au/pkcsm/admet prediction). Toxicity needs to be predicted because the parameter is required in clinical trials. If the compounds are toxic, they cannot be proposed to be the candidate for new drugs. Compound $\mathrm{KT} 1,3,5 \mathrm{OCH}_{3}$ has the biggest prediction $\mathrm{IC}_{50}$, almost $8 \mathrm{x}$ bigger than compound A5 which is 8.01739 . Data on all predictive activity and toxicity of modified compounds are presented in Table-3.

Table-3: Predictive Activity and Toxicity of Modified Compounds

\begin{tabular}{|c|c|c|c|c|c|c|}
\hline No. & Code & Compound & $\begin{array}{l}\mathrm{pIC}_{50} \\
(\mu \mathrm{M})\end{array}$ & AMES toxicity & Hepatotoxic & $\begin{array}{c}\text { Skin } \\
\text { Sensitization }\end{array}$ \\
\hline 1 & KT $1 \mathrm{OH}$ & $\mathrm{R} 1=\mathrm{OH}, \mathrm{R} 2=\mathrm{R} 3=\mathrm{R} 4=\mathrm{R} 5=\mathrm{H}$ & 4.85177 & yes & no & no \\
\hline 2 & KT $3 \mathrm{OH}$ & $\mathrm{R} 3=\mathrm{OH}, \mathrm{R} 1=\mathrm{R} 2=\mathrm{R} 4=\mathrm{R} 5=\mathrm{H}$ & 6.3425 & yes & no & no \\
\hline 3 & KT $1.2 \mathrm{OH}$ & $\mathrm{R} 1=\mathrm{R} 2=\mathrm{OH}, \mathrm{R} 3=\mathrm{R} 4=\mathrm{R} 5=\mathrm{H}$ & 3,59918 & yes & no & no \\
\hline 4 & KT $1,3 \mathrm{OH}$ & $\begin{array}{c}\mathrm{R} 1=\mathrm{R} 3=\mathrm{OH} \\
\mathrm{R} 2=\mathrm{R} 4=\mathrm{R} 5=\mathrm{H}\end{array}$ & 6.06145 & no & no & no \\
\hline 5 & KT $1,4 \mathrm{OH}$ & $\begin{array}{c}\mathrm{R} 1=\mathrm{R} 4=\mathrm{OH} \\
\mathrm{R} 2=\mathrm{R} 3=\mathrm{R} 5=\mathrm{H}\end{array}$ & 3.32983 & no & no & no \\
\hline 6 & KT $1,2,3 \mathrm{OH}$ & $\begin{array}{c}\mathrm{R} 1=\mathrm{R} 2=\mathrm{R} 3=\mathrm{OH} \\
\mathrm{R} 4=\mathrm{R} 5=\mathrm{H}\end{array}$ & 4.73196 & no & no & no \\
\hline 7 & KT $1,2,4 \mathrm{OH}$ & $\begin{array}{c}\mathrm{R} 1=\mathrm{R} 2=\mathrm{R} 4=\mathrm{OH}, \\
\mathrm{R} 3=\mathrm{R} 5=\mathrm{H}\end{array}$ & 2,32285 & no & no & no \\
\hline 8 & Kt $1,3,4 \mathrm{OH}$ & $\begin{array}{c}\mathrm{R} 1=\mathrm{R} 3=\mathrm{R} 4=\mathrm{OH}, \\
\mathrm{R} 2=\mathrm{R} 5=\mathrm{H}\end{array}$ & 4,47875 & no & no & no \\
\hline 9 & $\begin{array}{l}\text { 2nd Floor } \\
\mathrm{OCH}_{3}\end{array}$ & $\mathrm{R} 2=\mathrm{OCH}_{3}, \mathrm{R} 1=\mathrm{R} 3=\mathrm{R} 4=\mathrm{R} 5=\mathrm{H}$ & 6.65894 & no & no & no \\
\hline 0 & $\begin{array}{l}\text { 3rd place } \\
\mathrm{OCH}_{3}\end{array}$ & $\mathrm{R} 3=\mathrm{OCH}_{3}, \mathrm{R} 1=\mathrm{R} 2=\mathrm{R} 4=\mathrm{R} 5=\mathrm{H}$ & 6.90195 & no & no & no \\
\hline 11 & $1,2 \mathrm{OCH}_{3} \mathrm{Ct}$ & $\mathrm{R} 1=\mathrm{R} 2=\mathrm{OCH}_{3}, \mathrm{R} 3=\mathrm{R} 4=\mathrm{R} 5=\mathrm{H}$ & 5.39492 & no & no & no \\
\hline 12 & Kt $1,4 \mathrm{OCH}_{3}$ & $\mathrm{R} 1=\mathrm{R} 4=\mathrm{OCH}_{3}, \mathrm{R} 2=\mathrm{R} 3=\mathrm{R} 5=\mathrm{H}$ & 7.6404 & no & no & no \\
\hline 13 & $\begin{array}{l}\mathrm{Kt} 1.5 \\
\mathrm{OCH}_{3}\end{array}$ & $\mathrm{R} 1=\mathrm{R} 5=\mathrm{OCH}_{3}, \mathrm{R} 2=\mathrm{R} 3=\mathrm{R} 4=\mathrm{H}$ & 2.19696 & no & no & no \\
\hline 14 & $\begin{array}{l}\mathrm{Kt} 1,2,4 \\
\mathrm{OCH}_{3} \\
\end{array}$ & $\begin{aligned} \mathrm{R} 1=\mathrm{R} 2 & =\mathrm{R} 4=\mathrm{OCH}_{3} \\
\mathrm{R} 3 & =\mathrm{R} 5=\mathrm{H}\end{aligned}$ & 6,27738 & no & no & no \\
\hline 15 & $\begin{array}{l}\mathrm{Kt} 1,2,5 \\
\mathrm{OCH}_{3}\end{array}$ & $\begin{aligned} \mathrm{R} 1=\mathrm{R} 2 & =\mathrm{R} 5=\mathrm{OCH}_{3} \\
\mathrm{R} 3 & =\mathrm{R} 4=\mathrm{H}\end{aligned}$ & 7.13981 & no & no & no \\
\hline 16 & $\begin{array}{l}\mathrm{Ct} 2,3,4 \\
\mathrm{OCH}_{3} \\
\end{array}$ & $\begin{aligned} \mathrm{R} 2=\mathrm{R} 3 & =\mathrm{R} 4=\mathrm{OCH}_{3} \\
\mathrm{R} 1 & =\mathrm{R} 5=\mathrm{H}\end{aligned}$ & 5.79247 & no & no & no \\
\hline 17 & $\begin{array}{l}\mathrm{Kt} 1,3,4 \\
\mathrm{OCH}_{3} \\
\end{array}$ & $\begin{aligned} \mathrm{R} 1=\mathrm{R} 3 & =\mathrm{R} 4=\mathrm{OCH}_{3} \\
\mathrm{R} 2 & =\mathrm{R} 5=\mathrm{H}\end{aligned}$ & 5.67855 & no & no & no \\
\hline
\end{tabular}


RASĀYAN J. Chem.

Vol. 14 | No. 3 |2062-2067| July - September | 2021

\begin{tabular}{c|c|c|c|c|c|c}
\hline 18 & $\begin{array}{c}\mathrm{Kt} 1,3,5 \\
\mathrm{OCH}_{3}\end{array}$ & $\begin{array}{c}\mathrm{R} 1=\mathrm{R} 3=\mathrm{R} 5=\mathrm{OCH}_{3}, \\
\mathrm{R} 2=\mathrm{R} 4=\mathrm{H}\end{array}$ & 8,01739 & no & no & no \\
\hline 19 & $\mathrm{Kt} 1,2 \mathrm{I}$ & $\begin{array}{c}\mathrm{R} 1=\mathrm{I}, \\
\mathrm{R} 2=\mathrm{R} 3=\mathrm{R} 4=\mathrm{R} 5=\mathrm{H}\end{array}$ & 1,36975 & no & yes & no \\
\hline
\end{tabular}<smiles>[R3]c1c([R6])c([2H])c([R9])c(SCc2cc(=O)c(O)co2)c1[R3]</smiles>

Fig.-3: The Structure of Parent Compounds for Structural Modification

Molecular tethering is carried out with the enzyme tyrosinase ( $\mathrm{pdb}$ code: $2 \mathrm{y} 9 \mathrm{x}$ ) to see the interaction between compounds and amino acid residues of the enzyme. The validation is performed by redocking native ligands with the tyrosinase enzyme, which results in the RMSD values of $1.6 \AA$ ( $\leq 2 \AA)$ (Figure 4). This result indicated that the simulation can be continued to the molecular docking stage for each compound.

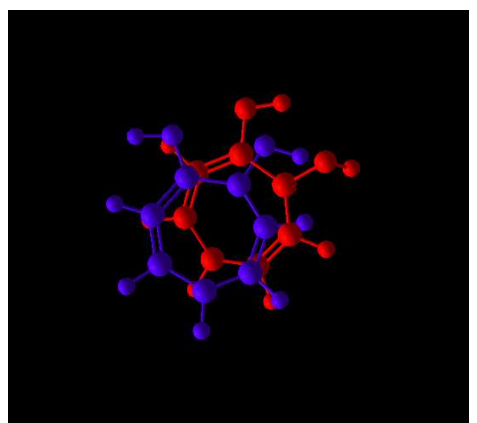

Fig.-4: 2y9x Molecular Docking Validation (Blue = Native Ligand, Red $=$ Redocking Ligand)
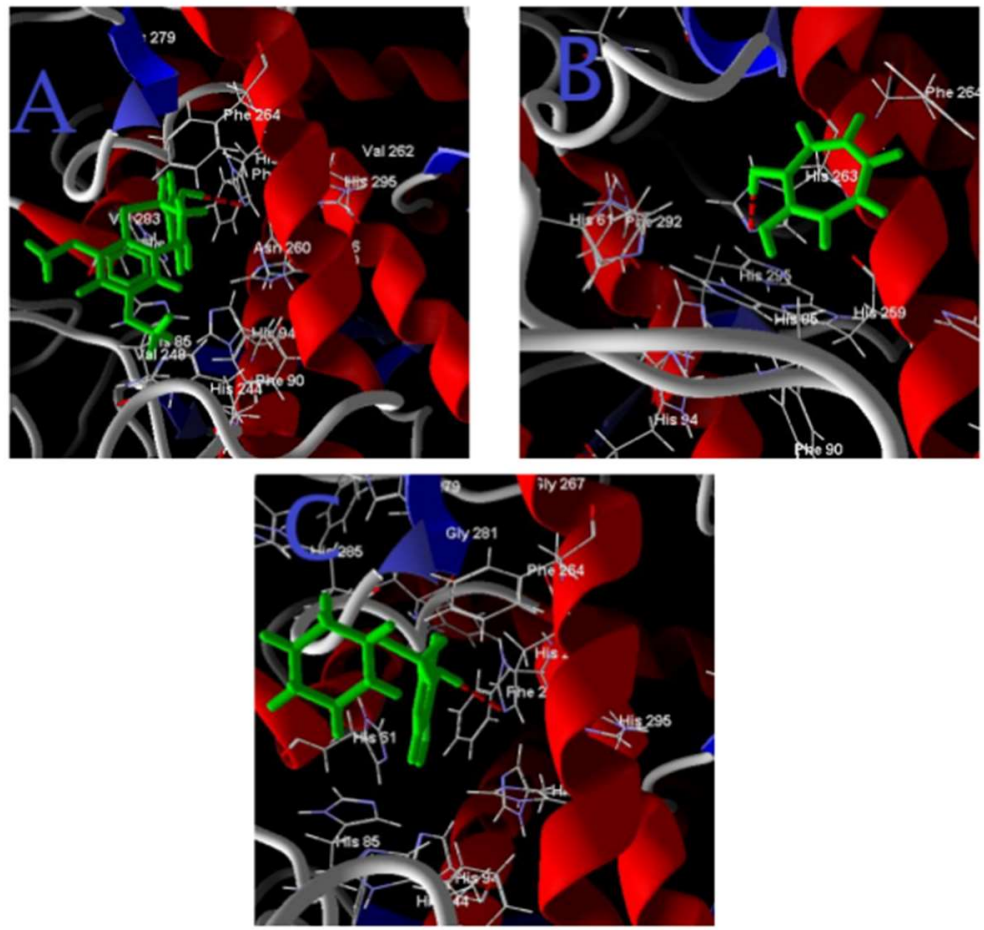

Fig.-5: Visualization of Interactions between Compounds and Amino Acid Residues His263 (Native Ligand (A), Compound A5 (B), Compound $\mathrm{KT} 1,3,5 \mathrm{OCH}_{3}(\mathrm{C})$, the Blue Line is Hydrogen Bond) 
RASĀYAN J. Chem.

Vol. 14 | No. 3 |2062-2067| July - September | 2021

There is at least one hydrogen bond between all compounds with amino acid residues of the tyrosinase enzyme. The amino acid residue is His 263 with a hydrogen bond distance of 1.63-3.44 $\AA$. In steric interactions of all compounds, His 263 amino acid residue is also involved. Compound A5 has one hydrogen bond with His 263 residue at a distance of $3.43 \AA$ and has a steric interaction on both amino acids His 263 and Phe264. Compound $\mathrm{KT} 1,3,5 \mathrm{OCH}_{3}$ has the largest value of $\mathrm{pIC}_{50}$. It shares the same hydrogen bond as compound A5. However, the steric interaction of compound $\mathrm{KT} 1,3,5 \mathrm{OCH}_{3}$ has additional two ammonia acid residues (Val248 and Asn260). Visualization of hydrogen compound bonds and the interaction of all compounds can be seen in Fig.-5.

\section{CONCLUSION}

In this research, QSAR equation models have been built to link structures of kojyl thiother compounds with their activities as tyrosinase inhibitors. Results exhibited that 15 out of 19 compounds have the potential to be new tyrosinase analog inhibitors. They are also less toxic. Compound $\mathrm{KT} 1,3,5 \mathrm{OCH}_{3}$ has the largest value of $\mathrm{pIC}_{50}$ and has an $\mathrm{IC}_{50}$ value eight times greater than the leading compound. The most important amino acid residue for hydrogen bonding and steric interactions is His263.

\section{ACKNOWLEDGEMENT}

The authors thank Professor Siswandono from the Faculty of the Pharmacy University of Airlangga who has been permitted to license Molegro Virtual Docker.

\section{REFERENCES}

1. S. K. Fistarol, P. H. Itin, Journal of the German Society of Dermatology, 8, 187(2010), https://doi.org/10.1111/j.1610-0387.2009.07137.x

2. J. M. Gillbro, M. J. Olsson, International Journal of Cosmetic Science, 33, 210(2011), https://doi.org/10.1111/j.1468-2494.2010.00616.x

3. R. V. Kundu, N. A. Vashi, British Journal of Dermatology, 169, 41(2013), https://doi.org/10.1111/bjd.12536

4. B. Deri, K. Margarita, G. Mor, L. Daniel, G. Victor, A. Noam, Scientific Reports, 6, 1(2016), https://doi.org/10.1038/srep34993

5. H.S. Rho, M.A. Soo, S.Y. Dae, K.K. Myung, H.C. Dong, Y.C. Jae, Bioorganic and Medical Chemistry Letters, 20(22), 6569(2010), https://doi.org/10.1016/j.bmcl.2010.09.042

6. B. Geetha, G. Swarnalatha, G.V.S. Reddy, Microwave Assisted Synthesis, Rasayan Journal Chemistry, 12(3), 1063(2019), http://dx.doi.org/10.31788/RJC.2019.1235165a

7. V.P. Saikishore, S.K. Biswal, R.K. Mohapatra, Rasayan Journal Chemistry, 14(1), 325(2021), http://dx.doi.org/10.31788/RJC.2021.1416205

8. F. Hermawan, J. Jumina, H. D. Pranowo, Rasayan Journal Chemistry, 13(4), 2626(2020), http://dx.doi.org/10.31788/RJC.2020.1345699

9. A. Masyita, Y. Rifai, International Journal of Bioscience, Biochemistry and Bioinformatics, 9, 188(2019)

[RJC-6343/2020] 